PATRYCJA ROJEK

Instytut Filmu, Mediów i Sztuk Audiowizualnych Uniwersytet im. Adama Mickiewicza w Poznaniu

\title{
Figura mitologicznej Kasandry $w$ filmach science fiction
}

\begin{abstract}
Rojek Patrycja, Figura mitologicznej Kasandry $w$ filmach science fiction [The mythical figure of Cassandra in science fiction films]. "Images" vol. XXVIII, no. 37. Poznań 2020. Adam Mickiewicz University Press. Pp. 233-246. ISSN 1731-450X. DOI 10.14746/i.2020.37.14.

The article reflects on how characters with the features of the mythological Cassandra function in science fiction films. Such references are part of the rich tradition of building fictional depictions of the near or distant future on the foundation of mythical stories. The study aimed to examine the considerable and complex meaning which Cassandra conveys through the ages and to determine its usefulness in constructing pop culture ideas about the current condition of humanity. In contemporary fiction, Cassandra is brought to the fore more often than in ancient sources, and her fullest portrait is drawn in those films that both consider her a figure of the powerlessness of the prophets and take into account her personal drama. In Terminator 2: Judgment Day (1991) by James Cameron, 12 Monkeys (1995) by Terry Gilliam, Minority Report (2002) by Steven Spielberg, and Arrival (2016) by Denis Villeneuve, the figure of Cassandra is examined through her prophetic gift, the alleged madness of the seer and the fearfulness of the prophetism itself.
\end{abstract}

KEYwORDs: Greek mythology, science fiction, myth in film, Cassandra, prophetism, Terminator 2: Judgment Day, James Cameron, 12 Monkeys, Terry Gilliam, Minority Report, Steven Spielberg, Arrival, Denis Villeneuve

Kulturowy żywot władającej darem wieszczenia córki Priama i Hekabe nie zakończył się bynajmniej w domu Agamemnona, choć większość antycznych poetów zgadza się, że to tam właśnie poniosła śmierć z rąk Klitajmestry i jej kochanka Ajgistosa. Kasandra od wieków powraca w rozmaitych testach kultury, funkcjonując w nich w roli łączniczki między racjonalną doczesnością i tym, co niezgłębione. Postacie tego typu Elżbieta Wesołowska nazywa za Ewą Gorlewską plastyczny$\mathrm{mi}$ - żyjącymi poza czasem i przestrzenią, a przez to reprezentującymi problemy z wielu obszarów nauki - między innymi socjologii, psychologii i medycyny[1]. W tym artykule przedmiotem refleksji będzie przede wszystkim funkcjonowanie Kasandry poza czasem (lub raczej: ponad czasem lub pomimo czasu) w nieco bardziej dosłownym znaczeniu, bo w ekranowych opowieściach, w których to właśnie czas jest głównym obiektem zainteresowania.

Budowanie fikcjonalnych wyobrażeń o bliższej lub dalszej przyszłości na fundamencie znanych od wieków opowieści to zjawisko dobrze znane najpierw w obszarze literatury science fiction, później
Images

vol. XXVIII/no. 37

Poznań 2020

ISSN 1731-45OX 
również filmu. Thomas C. Sutton i Marilyn Sutton obserwują w fantastycznonaukowych fabułach tę samą co w mitach próbę odwzorowania sensu istnienia poprzez uspójnienie tego, co wewnątrz, z tym, co na zewnątrz. Formuła mitu pozwala na zaistnienie autonomicznego świata, który pozostaje w metaforycznej relacji ze światem rzeczywistym[2]. Popkulturowe opowieści o heroicznych naukowcach, potworach z kosmosu i wyprawach na odległe planety mogą z powodzeniem pełnić te same funkcje, co mity przed wiekami - objaśniać, porządkować, ale i wyrażać najaktualniejsze nadzieje i obawy. I bez wątpienia jako takie znacznie skuteczniej budują współczesną mitologię niż upowszechniają wiedzę naukową[3]. W niniejszych rozważaniach podejmuję się jednak zbadania konkretnej manifestacji tego zjawiska i jedynie w wybranych filmach, mając świadomość ich funkcjonowania w ramach długiej i bogatej tradycji fantastycznonaukowej fikcji zbudowanej na solidnych literackich fundamentach. Tym samym, dokonując swoistego skoku $z$ antycznej przeszłości w szeroko ujmowaną teraźniejszość (a może nawet: w niedokonaną jeszcze przyszłość), porządkuję jedynie pewne tropy i wskazuję powiązania, które z pewnością warte są dalszego zgłębiania.

Za główną przyjmuję w tym artykule optykę mitoznawczą, mit zaś traktuję przede wszystkim jako opowieść osadzoną w serii tematycznej. Powracający we wszystkich przywoływanych filmach temat Kasandry rozumiem w myśl założeń Janiny Abramowskiej jako temat imienny - odsyłający do pewnej sytuacji elementarnej, pewnego przebiegu fabularnego, pewnego osobowego charakteru lub postawy[4]. Celem badania jest - poprzez nakreślenie zakresu i sposobu oddziaływania tego tematu we wskazanych filmach science fiction - ukazanie pokaźnego i złożonego ładunku znaczeniowego, jaki ze sobą niesie, oraz ustalenie jego przydatności w konstruowaniu popkulturowych wyobrażeń o aktualnej kondycji ludzkości. Bo, jak przekonywała Abramowska: pamięć ideowa konkretnych tematów imiennych odpowiada uogólnionej mentalności przedstawicieli poszczególnych epok. „Mitem-kluczem” lepiej niż inne wyrażającym światopogląd epoki był w romantyzmie mit Prometeusza, w modernizmie mit Dionizosa[5]. Być może mit teraźniejszości stojącej u progu budzącej obawy przyszłości to właśnie mit Kasandry?

Poszukiwanie Kasandry w utworach często nienawiązujących nawet eksplicytnie do opowieści mitycznych nie jest zadaniem łatwym. Już same antyczne źródła kreślą kilka jej wizerunków, często różniących się zasadniczo. Próbę ich uporządkowania podejmuje Elżbieta Wesołowska w artykule o znaczącym tytule Dwie lub trzy Kasandry i co o nich wiem:

[2] T.C. Sutton, M. Sutton, Science fiction as mytho$\log y$, „Western Folklor” 1969, vol. 28, nr 4, s. 232. [3] „Unlike a scientific hypothesis, a science fiction story is not formulated primarily to advance technological knowlege; rather it operates on visionary, mythopeic level". Ibidem, s. 255-236.
[4] J. Abramowska, Powtórzenia i wybory. Studia z tematologii i poetyki historycznej, Poznań 1995, s. 36-37. [5] Abramowska przytacza to przyporządkowanie za Michałem Głowińskim. Ibidem, s. 41. 
Już ich liczba nie jest oczywista. Są bowiem dwie córki Priama, jeśli myślimy o aspekcie genologicznym. Jest to bowiem Kasandra tragediowa (Ajschylos, Eurypides i Seneka) versus epicka (Homer i Wergiliusz), z tak znaczącą przewagą na rzecz tragedii, że ten podział nie spełnia swego podstawowego celu, nie ukazuje dwóch jakości, w rzymskim eposie bowiem Kasandra nie mówi ani słowa! Jest z kolei Kasandra autorska, bo każdy z wielkich pisarzy choć trochę się przyłożył do jej dookreślenia: Homer, Ajschylos, Eurypides i Seneka. Wergiliusz jest tutaj znów na boku. Można również dostrzec Kasandrę grecką i rzymską. O dziwo, ten podział jest najmniej wyrazisty. Wszak w ramach greckiej kategorii Eurypides w swych Trojankach skonstruował postać Kasandry przeciw tradycji, czyniąc z niej Erynię zemsty, więc bynajmniej nie ofiarę wojny i losu, jak to sobie zaplanował Ajschylos[6].

Wymienione Kasandry łączy samotność, niezrozumienie, ignorowanie jej słów i izolacja wskutek klątwy Apolla[7], który najpierw obdarza kobietę darem wieszczenia, a później karze ją społecznym odrzuceniem. Jerzy Stempowski we wstępie do Eseju do Kassandry nazywa ją „postacią symboliczną przedstawiającą dramat wewnętrzny i bezsilność proroków" [8]. Te atrybuty będą również stanowiły podstawę analizy postaci filmowych identyfikowanych jako kulturowi spadkobiercy i (częściej) spadkobierczynie Kasandry.

Wspomniani badacze zwracają również uwagę na przewagę reprezentacji Kasandry w formach tragediowych w porównaniu z epickimi. Zarówno w Eneidzie, jak i w Odysei Kasandra jest zaledwie postacią epizodyczną. Również w Iliadzie - jak wskazuje Stempowski - nie ma miejsca na dialog proroka $\mathrm{z}$ jego ludem.

Dialog taki należy do świata republikańskiego. Tam dopiero występuje różnica między tym, który widzi, i jego niewidomym otoczeniem. Postać Kassandry tragicznej jest tworem wyobraźni ateńskiej, wzrastającym i dopełniającym się w demokracji[9].

Diagnoza ta trafnie opisuje podobne zależności w badanej przeze mnie materii filmowej. Istotnie, współczesna Kasandra zyskuje na znaczeniu w świecie zhierarchizowanym. Najwymowniejsza staje się wówczas, gdy jest konfrontowana z całymi systemami politycznymi - jak w Terminatorze 2 (1991) Jamesa Camerona, 12 małpach (1995) Terry'ego Gilliama, Raporcie mniejszości (2002) Stevena Spielberga oraz przede wszystkim w Nowym początku (2016) Denisa Villeneuve’a. W każdym z tych filmów postać o cechach Kasandry jest konstruowana poprzez wejrzenie w jej osobisty dramat.

Drugi z wyrazistych wariantów ekranowego funkcjonowania Kasandry wiąże się ściśle z konwencją filmu o katastrofie[10]. Kasandra sprowadzona jest w nich zazwyczaj do jednej funkcji: bezskuteczne-

[6] E. Wesołowska, op.cit., s. 44.

[7] Ibidem.

[8] J. Stempowski, Esej dla Kassandry, [w:] idem,

Eseje dla Kassandry, red. P. Kłoczowski, Gdańsk 2005, s. 28.

[9] Ibidem.
[10] Za Susan Sontag włączam temat katastrofy do przestrzeni właściwej filmowi science fiction. Należy jednak podkreślić, że film o katastofie bywa w dyskursie filmoznawczym klasyfikowany również jako wariant horroru lub całkowicie odrębny gatunek. S. Sontag, Katastrofa w wyobrażeniu, [w:] eadem, 
go ostrzegania przed klęską w czasie, gdy można jej jeszcze zapobiec. Kasandrami mogą być wówczas niedoceniani ludzie nauki (zwłaszcza w filmach Rolanda Emmericha: technik satelitarny David Levinson w Dniu Niepodległości, paleoklimatolog Jack Hall w Pojutrze, geolog Adrian Helmsley w 2012), wyznawcy teorii spiskowych (Alan Krumwiede w Epidemii strachu, Charlie Frost w 2012) lub uliczni głosiciele końca świata. Zwłaszcza w drugim i trzecim przypadku są to osoby długo funkcjonujące na obrzeżach i często tam pozostające również w fabule - jako postacie trzecioplanowe i epizodyczne. Filmy o katastrofie to bowiem widowiska o zdecydowanie epickim nacechowaniu, jednoznacznie gloryfikujące postawy heroiczne. O ile więc Kasandra nie uciszy swojej potrzeby głoszenia nieuchronności klęski i sama nie stanie się heroiną, może być jedynie zwierciadłem dla innego bohatera, który wskutek spotkania z nią zamiast tylko mówić o katastrofie, realnie jej zapobiegnie.

W 1934 roku w opublikowanym w „Film Culture” eseju Epic and Dramatic Film[11] Rudolf Arnheim opisał podział filmów ze względu na działania bohatera, wyodrębniając filmy dramatyczne (dramatic films) i filmy epickie (epic films). Rozróżnienie to wywiódł z koncepcji Goethego z 1797 roku wyrażonej w tekście O poezji epickiej i dramatycznej[12], która zakłada, że poezja epicka przedstawia bohatera kierującego swoje działania na zewnątrz - pogrążonego w żywiole bitew, podróży, wypraw, spośród których wszystkie domagają się szerokiego pola przedstawieniowego. Odwrotnie jest z kolei z poezją dramatyczną, orientującą działania bohatera na własne wnętrze w podróży głębokiej w sensie poznawczym: emocjonalnym, duchowym i intelektualnym, podróży często niewymagającej szerokiej przestrzeni. Ten podział nie pokrywa się wprawdzie z rozróżnieniem dwóch typów Kasandr w filmach science fiction, stanowi natomiast jeden z możliwych powodów, dla których dola Kasandry nie wybrzmiewa w epice tak sugestywnie, jak w tragedii. We współczesnych tekstach kultury częściej niż w antycznych źródłach Kasandra wysuwana jest na pierwszy plan. W istocie jednak najpełniejszy jej obraz rysuje w tych filmach, które rozpatrują ją jako figurę „bezsilności proroków” bez pomijania jej „dramatu wewnętrznego" - posługując się określeniami Stempowskiego. Niniejsze rozważania poświęcam zatem filmowym reprezentacjom Kasandry pokazującym naturę jej dramatu w sposób złożony i pogłębiony w stopniu przynajmniej zbliżonym do tego, który prezentują w swoich utworach greccy tragicy.

\section{Szaleństwo}

Giorgio Colli w Narodzinach filozofii przekonuje, że wnikliwe wejrzenie w przyszłość człowieka i świata dla antycznych Greków było

Przeciw interpretacji i inne eseje, tłum. A. Skucińska, Kraków 2012.

[11] R. Arnheim, Epic and dramatic film, „Film Culture" 1957, nr 3, s. 9-10.
[12] J.W. Goethe, O poezji epickiej i dramatycznej, [w:] Goethe i Schiller o dramacie i teatrze. Wybór pism, tłum. i oprac. O. Dobijanka-Witczakowa, Kraków 1996, s. 108-110. 
jednym z zadań mądrości[13]. „Wiele narodów uciekało się do wieszczenia i je gloryfikowało, ale żaden inny naród, prócz Greków, nie nadał mu rangi rozstrzygającego symbolu, mającego świadczyć o tym, że najwyższy stopień mocy ludzkiej wyraża poznanie”[14]. I tak źródeł filozofii rozumianej po platońsku jako „umiłowanie mądrości” Colli upatruje w istnieniu mędrców wcześniejszych od tych, których znamy jako pierwszych greckich filozofów. Sam Platon miał z rewerencją spoglądać wstecz na czasy, w których żyli jeszcze „mędrcy”. Mądrość ostatecznie była według niego czymś innym niż „umiłowanie mądrości”, filozofia nie zdobywa bowiem niczego od nowa, ale dąży do odzyskania tego, co zostało zdobyte i przeżyte dużo wcześniej. Idąc za Nietzschem, który podobnie opisywał narodziny i schyłek tragedii, Colli sięga do świata wyobrażeń i pojęć wywodzących się z tradycji religijnej i rozumianych jako symbole, by odtworzyć historię antycznej greckiej mądrości, której jedynie końcowy fragment jest dobrze udokumentowany - przez dzieła tych, których dziś uważamy za ojców filozofii[15].

W Timaiosie Platona czytamy jednak, że mędrcy to nie ci, którzy otrzymują „boskie słowo”, ale ci, którzy je tłumaczą. Wieszczowie to zatem nie mędrcy: „Bo żaden rozumny człowiek nie ma nic wspólnego z wieszczbiarstwem, pochodzącym od boga i prawdziwym [...]. To nie jest rzeczą człowieka obłąkanego, jak długo w obłąkaniu trwa, oceniać to, co mu się przywiduje, ani to, co z jego ust wychodzi"[16]. Traktowanie wieszczów jako szaleńców wynika między innymi z zagadkowej natury samej przepowiedni: aluzyjnej, pogrążonej w nieładzie, jakby była sformułowana przez bóstwo w taki sposób, by słuchacz nie mógł jej pojąć, a ten, który ją wypowiada, brzmiał jak obłąkany.

U Ajschylosa w Agamemnonie Klitajmestra już przy pierwszym spotkaniu nazywa Kasandrę szaloną i słuchającą „myśli swoich pomieszanych"[17]. Natomiast u Eurypidesa w Trojankach w słowach jej zatroskanej matki Hekabe wieszczka jawi się jako „opętana” i „gnana szałem”[18]. Jej szaleństwo ma ścisły związek z darem pochodzącym od Apolla, który jest uważany za bóstwo maniczne. Cztery kategorie boskiego szału wymienia Platon w Fajdrosie - mistyczne natchnienia przypisując Dionizosowi, poetyckie Muzom, miłosne Afrodycie i Erosowi, a prorocze właśnie Apollonowi[19].

Piętno szaleńca dotyka również większość zbadanych filmowych wieszczów - mimo że źródła ich daru w żadnym przypadku nie da się utożsamić z boskim natchnieniem. Fantastyka naukowa upatruje tych źródeł bliżej człowieka i jego naukowych aktywności: osiągnięć lub porażek. W świecie Ameryki roku 2054 wykreowanym w Raporcie mniejszości umiejętność przewidywania przyszłości pojawia się wskutek uszkodzenia mózgu jasnowidzów - wrodzonej wady spowodowanej za-

[13] G. Colli, Narodziny filozofii, wstęp i tłum. S. Kasprzysiak, Warszawa, Kraków 1991, s. 25.

[14] Ibidem, s. 26-27.

[15] Ibidem, s. 23-24.

[16] Platon, Timaios, 71E-72A, tłum. W. Witwicki.
[17] W przekładzie Stefana Srebrnego. Ajschylos, Agamemnon, w. 1063.

[18] W przekładzie Jana Kasprowicza. Eurypides, Trojanki, w. 306-307.

[19] Platon, Fajdros, 265B, tłum. W. Witwicki. 
żywaniem przez ich rodziców neuroiny, silnie uzależniającej substancji psychoaktywnej. Z ich wizji korzysta natomiast państwo w testowym programie prewencyjnym, w wyniku którego przyszli sprawcy najcięższych przestępstw mogą być ujęci, zanim jeszcze dokonają zabronionego czynu. Jest to zatem świat, w którym wierzy się wieszczom, choć ich samych nie traktuje się na równi z innymi ludźmi. Ubezwłasnowolnieni i zdehumanizowani jasnowidze - dwaj mężczyźni i kobieta o imieniu Agatha (Samantha Morton), najzdolniejsza z całej trójki - są zmuszani w imię wspólnego dobra do ciągłego przeżywania okrutnych zbrodni z przyszłości, otrzymując w zamian „własną sypialnię, telewizję i siłownię" - o ile uznamy telewizyjną propagandę za rzetelne źródło informacji. W rzeczywistości utrzymywani są w stanie stałego odurzenia za pomocą dopaminy i endorfin, co do złudzenia przypomina działanie delfickiej wyroczni wprowadzanej w trans przez kapłana za pomocą palonych nad lampą oliwną ziaren jęczmienia, konopi i lauru[20]. Rolę kapłanów w świecie Spielberga przyjmują przedstawiciele systemu: niczym platońscy mędrcy tłumaczący wizje szaleńców, w których według głównego protagonisty (Tom Cruise) „lepiej nie widzieć ludzi”[21]. W odpowiedzi na te słowa bohater usłyszy: „Wyrocznia nie ma władzy. Władzę mają kapłani, jej twórcy".

Wydaje się, że w możliwości systemowego sprawowania kontroli nad wieszczem tkwi warunek jego społecznej akceptowalności - zarówno w przedstawieniach mitologicznych, jak i we współczesnych wyobrażeniach na temat przyszłości. Ten aspekt różni Pytię od Kasandry, mimo że obie wieszczki czerpały swoje umiejętności z jednego źródła: apollińskiego natchnienia. Z nich dwóch jednak tylko Kasandra była tą niepokorną, upartą i szaloną w sposób, który mógł zagrażać społecznemu porządkowi. Symptomatyczne jest to, że we współczesnej fikcji szaleństwo to nie tylko społeczny stygmat, ale i realna podstawa do wdrożenia instytucjonalnej izolacji. Sarah Connor (Linda Hamilton) w filmie Terminator 2: Dzień Sadu trafia do szpitala psychiatrycznego ze zdiagnozowanymi zaburzeniami schizotypowymi. Tu również, podobnie jak w Raporcie mniejszości, odurzenie lekami staje się środkiem opresji wobec niej. Jednak wbrew intencji lekarzy to właśnie podawane siłą substancje sprawiają, że Sarah widzi nadchodzącą apokalipsę (tytułowy Dzień Sądu), choć jej wizje konsekwentnie nazywane są urojeniami. Znamienne wydaje się również to, że w wizjach Sary pojawia się jej zmarły ukochany, Kyle Reese. To za jego sprawą Sarah w pierwszej części serii uzyskiwała wiedzę o przyszłości, z której przybył Kyle. W pierwszym filmie z 1984 roku to on ostrzegał przed katastrofą i był z tego powodu uznawany za szaleńca.

James Cameron oddziela jednak niewiarę otoczenia Sary od perspektywy widza, który od początku ma stać po jej stronie. Terminator 2 rozpoczyna się bowiem obrazami z roku 2029. Nie są one jednak 
przedstawione w formie proroczej wizji, lecz jako coś, co autentycznie miało miejsce - uwiarygodnia to pozadiegetyczny podpis „Los Angeles, 2029 A.D.” oraz prowadzona z offu narracja Sary (słyszymy: „Życie trzech miliardów ludzi skończyło się 29 sierpnia 1997 roku. Ci, którzy przetrwali, nazwali ten dzień Dniem Sądu. Przeżyli tylko po to, by stawić czoło nowemu koszmarowi. Wojnie przeciwko maszynom"). Co ciekawe, bardzo podobny zabieg został zastosowany w zupełnie innym celu przez Terry'ego Gilliama w 12 małpach. Ekspozycję poprzedza plansza z informacją: „W roku 1997 śmiertelny wirus zabije 5 miliardów ludzi. Nieliczni, którzy przeżyją, ukryją się pod ziemią. I zwierzęta na powrót przejmą panowanie nad światem”. Po chwili jednak pojawia się podpis: „Fragmenty wywiadu lekarskiego z chorym na schizofrenię paranoidalną w Szpitalu Okręgowym w Baltimore, 12 kwietnia 1990 roku" [22]. Wiarygodność głównego bohatera i autora tych słów, Jamesa Cole’a (Bruce Willis), długo nie będzie jasna, również dla widza. Niepewny status Cole’a (przybywającego z postapokaliptycznej przyszłości po materiał biologiczny, który pomoże stworzyć ratującą ocalałych szczepionkę) jest także podkreślany przez częste stosowanie ukośnej perspektywy (Dutch angles). Choć bohater wygląda i zachowuje się jak szaleniec, w kluczowym momencie przyznaje, że szaleństwo byłoby dla niego wybawieniem. Mógłby wtedy żyć spokojnie w bezpiecznym szpitalu i nie martwić się o to, co nadejdzie. Tymczasem przekonanie o własnej racji jest w nim niezachwiane. Z perspektywy niniejszych rozważań najistotniejsze wydaje się to, że 12 małp to film, w którym odniesienia mitologiczne są wyrażone wprost. Diagnozująca Cole’a lekarka opisuje bowiem jego przypadłość terminem „kompleks Kasandry”, który ma oznaczać związane z wewnętrznym cierpieniem przekonanie o tym, że straszna przyszłość już się dokonała i nic nie można na to poradzić[23]. Ostatecznie niezachwiana pewność Cole’a i ją przekona, że czasem najprostszym uzasadnieniem posiadania wiedzy o przyszłości jest jej autentyczne przeżycie.

Motyw podróży w czasie doskonale łączy się z figurą mitologicznej Kasandry z co najmniej dwóch powodów. Po pierwsze: dla postaci obdarzonych współczesną świadomością podróż w czasie jest niemożliwa - zatem osoba podająca się za przybysza z przyszłości nie może być uznana za wiarygodną. Po drugie jednak: uzasadnienie podróży technologią, którą dopiero powstanie, ustanawia osobiste doświadczenie podróżnika jedynym źródłem wiedzy o przyszłości - całkowicie niezależnym od pierwiastka nadprzyrodzonego. Temat uwalniania się od poczucia nieuchronnej zależności od tego, co niezrozumiałe, już dla starożytnych Greków był istotną aspiracją i ostateczną przyczyną przejścia od mądrości proroków do mądrości filozofów. Według Andrzeja Ledera „Sfera boska i ludzka są absolutnie różne, a jednocześnie

[22] W przekładzie Marka Nowińskiego.

[23] W serialowym remake'u 12 małp, tworzonym przez Terry'ego Matalasa oraz Travisa Ficketta w la- tach 2015-2018 jedna z głównych bohaterek nosiła nawet imię Cassandra. 
sąsiadują ze sobą tylko o włos. Sfera ludzka nie jest jednak samoistna, jest miejscem ujawniania się boskiej «inności»"[24]. Uniezależnienie sfery ludzkiej od boskiej może zaistnieć w momencie przejęcia jej cech konstytutywnych - władza nad czasem jest w tym wypadku z nich. Co ciekawe, kwestia wiary ma wówczas niezmiennie ogromne znaczenie nie jest to jednak wiara w istnienie bóstwa, lecz wiara w autentyczność relacji podróżnika. Patrząc na filmy science fiction jako na wytwory współczesnej mitologii, można odnieść wrażenie, że są one opowieściami o nieograniczonych ludzkich możliwościach. Ostatecznie racja jest po stronie tych, którzy w wieszczeniu Kasandry potrafią dostrzec nie nieuchronność zagłady, ale szansę na jej powstrzymanie. Bo jak przekonywał Sarę Connor Kyle Reese: „Przyszłość nie jest ustalona. Nie ma przeznaczenia poza tym, które ukształtujemy sami”[25]. Ale czy zawsze?

Groza

Pytanie o możliwość odwrócenia biegu wydarzeń jest jednym z częściej zadawanych w wyprodukowanych w ostatnich dekadach filmach i serialach science fiction. Rozwiązania pozytywnie rozstrzygające tę kwestię (jak u Spielberga i Camerona) znacznie częściej ustępują deterministycznym wizjom, w ramach których każda próba dokonania zmian ostatecznie okazuje się tym czynnikiem, który do nich doprowadził. Jak choćby w przypadku Cole’a z 12 małp, który $\mathrm{w}$ finale przekonuje się, że jego wspomnienie z dzieciństwa dotyczy spotkania starszej wersji samego siebie. Podobnie jak bohaterowie filmu Looper (2012) Riana Johnsona czy ostatnio serialu Dark (2017-2020) produkcji Netflixa, Cole zostaje uwięziony w pętli czasowej. Czy raczej: w zamkniętej krzywej czasopodobnej - zjawisku, które według Stephena Hawkinga nie może zaistnieć w znanej nam rzeczywistości ze względu na tak zwane przypuszczenie ochrony chronologii (chronology protection conjecture). I choć rola determinizmu w fikcjonalnych wyobrażeniach na temat przyszłości to temat na odrębne rozważania, w kontekście wykrzykiwanych przez Kasandrę ostrzeżeń o katastrofie ma ona szczególne znaczenie.

Giorgio Colli wskazuje, że dla starożytnych Greków przewidywanie przyszłości nie było związane z konkretnym, z góry ustalonym ciągiem wydarzeń. „Jeśli ktoś widzi wcześniej coś, co ma nastąpić za minutę czy za tysiąc lat, nie ma to jeszcze nic wspólnego z kolejnym następowaniem po sobie faktów czy spraw, które tę przyszłość będą tworzyć" [26]. Wróżba to dla Greków ujawnienie znajdującej się poza czasem realności boskiej, która zawiera jedynie zarodek przyszłego wydarzenia. Wieszcz widzi zatem wyrwany z kontekstu fragment tego, co nadejdzie - nie zaś ciąg faktów, który do niego doprowadzi. Dla Colliego jest to wyrazem boskiej bezmierności: kapryśnej, wyniosłej,

[24] A. Leder, Paradoks a filozofia. Niesamoistność człowieka w Grecji archaicznej, „Sztuka i Filozofia” 2003, $\mathrm{nr} 22-23$, s. 186.
[25] W przekładzie Bartosza Zimińskiego.

[26] G. Colli, op.cit., s. 50. 
niemożliwej do zgłębienia[27]. Wydaje się zatem, że funkcjonujący w tym mechanizmie człowiek ma wprawdzie możliwość dokonania wyboru, lecz nie jest zdolny do umknięcia przeznaczeniu - o czym przekonał się choćby Edyp. Kwestię współistnienia determinizmu i wolnej woli w świecie greckim Jan Kott rozważa za pomocą metafory pułapki, która czeka na mysz, choć nikt jej nie nastawił - pułapka po prostu jest. Mysz ma wolną wolę. Pułapka natomiast ma nieskończenie wiele czasu i czeka, aż mysz popełni błąd, co w końcu musi nadejść - bo to, że mysz musi przegrać w tej grze, zostało już ustalone[28].

Mechanizm ten najsilniej wybrzmiewa wówczas, gdy wróżba opisuje wydarzenia tragiczne. A tylko takich dotyczyły najsłynniejsze przepowiednie Kasandry - zniszczenia Troi, zabicia Agamemnona oraz jej samej. W pierwszym odczuciu można byłoby odnieść wrażenie, że gdyby ktoś zawczasu uwierzył w proroctwa wieszczki, dałoby się uniknąć tragedii. Na tym poziomie refleksji o naturze ostrzeżenia Kasandry pozostają wspomniane wcześniej filmy katastroficzne. Natomiast w filmach o nacechowaniu dramatycznym oddziaływanie nieuchronności losu jest dużo intensywniejsze - nie zawsze jednak stawienie oporu wobec niej skazane jest na porażkę. Sarze Connor ostatecznie udaje się przecież „odłożyć” Dzień Sądu na bliżej nieokreślony czas, a James Cole wprawdzie sam ginie, lecz dzięki jego działaniom możliwe będzie wynalezienie leku ratującego życie ocalałych z epidemii. Jedynie Raport mniejszości zostawia z przekonaniem, że posiadanie wiedzy o przyszłości - zwłaszcza w jej najciemniejszej wersji - jest zbyt niebezpieczne, byśmy mogli swobodnie nią dysponować.

Ten ostatni wniosek najlepiej koresponduje z myśleniem starożytnych. Według Radosława Piętki profetyzm z założenia wiązał się dla Greków z grozą i lękiem przed tym, co niepojmowalne, a wieszczenie samo w sobie oznaczało przede wszystkim: przepowiadanie nieszczęść. Kasandra (zwłaszcza u Ajschylosa) stanowiła według badacza wcielenie grozy jako postać „rozsiewająca wkoło przerażenie zarówno swoimi słowami, jak i własnym strachem" [29]. Antyk grecki był ponadto zdominowany - podobnie jak wiele innych dawnych kultur - przez umocowaną w micie złotego wieku regresywną wizję czasu. Oznacza to, że idealizowana przeszłość była zawsze oceniana wyżej niż teraźniejszość i przyszłość, a każde kolejne pokolenie uznawane było za coraz bardziej zdegenerowane[30]. Znamienne w tym kontekście wydaje się zakończenie filmu Spielberga. Choć w zbudowanym w nim świecie przepowiednie sprawdzały się jako środek policyjny prewencyjny (czyli de facto: nie wypełniały się), były częścią okrutnego systemu karzącego za niepopełnione zbrodnie[31] i wyniszczającego samych

[27] Ibidem, s. 50-51.

[28] J. Kott, Tragedia grecka i absurd, [w:] Zjadane bogów. Szkice o tragedii greckiej, red. K. Brablec, Kraków 1986, s. 279.

[29] R. Piętka, Profetyzm i historia. Temat Sybilli w literaturze dawnej i dwudziestowiecznej, [w:] Narracja, historia, fikcja. Dawne kultury w historiografii i literaturze, red. Ł. Grüzmacher, Warszawa 2009, s. 84. [30] Ibidem, s. 85.

[31] Podobne wizje dotyczące systemowej oceny jednostki zrealizowane zostały między innymi $\mathrm{w}$ filmie Gattaca (1997, reż. Andrew Niccol) oraz w 3. sezonie 
wieszczów. Agatha mówi, że jest zmęczona przyszłością. W ostatniej scenie - a zarazem jedynej zrealizowanej w ciepłych barwach i przy miękkim świetle zachodzącego słońca - widzimy ją i jej dwóch towarzyszy otoczonych książkami. Kontakt z literaturą staje się zbawienną możliwością zanurzenia w przeszłość po latach udręki związanej z oglądaniem odrażającej przyszłości.

Wydaje się zatem, że figura mitologicznej Kasandry wciąż w czytelny sposób obrazuje ogólniejszą niechęć do patrzenia w przyszłość jako aktu zwodniczego, niebezpiecznego i uwydatniającego brak ludzkiej sprawczości. Szczególnie silnie wybrzmiewa to we współczesnych utworach dotyczących przyszłości - samo ich powstanie również jest przecież snuciem wizji na temat tego, co mogłoby się zdarzyć. Zbudowana na określonej konwencji gatunkowej fikcjonalność filmowych wizji niweluje wprawdzie grozę, lecz wciąż pozostawia z pytaniami o społeczne funkcjonowanie przepowiedni: jak ludzkość dziś zachowałaby się w obliczu zetknięcia z proroctwem? Tę kwestię w najznakomitszym stopniu zgłębia Nowy początek.

Komunikacja

W rozważaniach na temat wyprodukowanego w 2016 roku filmu Denisa Villeneuve'a spotkają się niemal wszystkie poruszone dotąd wątki - z Nowego początku wyłania się tym samym najbardziej kompleksowy wizerunek współczesnej wieszczki. Tym samym najpełniej uwidacznia się w nim rozstrzygnięcie kwestii zarysowanej na początku tego artykułu: czy mit Kasandry może zafunkcjonować jako mit teraźniejszej epoki zdominowanej przez obawy o nadchodzącą przyszłość?

Scenarzysta Villeneuve'a, Eric Heisserer, adaptując opowiadanie Historia twojego życia Teda Chianga, dodaje do wątku profesjonalnego i osobistego głównej bohaterki wątek polityczny i wpisuje całość w konwencję filmu o (nadchodzącej) katastrofie. Tym samym utrzymywana jest aura ciągłego napięcia związanego z oczekiwaniem na wybuch konfliktu zbrojnego z przybyszami z kosmosu. Zajmująca się naukowo lingwistyką dr Louise Banks (Amy Adams) o lądowaniu dwunastu obcych statków dowiaduje się - jak wszyscy - z mediów. Jej rolą nie będzie więc ostrzeganie, ale rozpracowanie języka przybyszy i zadanie im najważniejszego pytania o cel ich przybycia na Ziemię. Wizje dotyczące przyszłości pojawią się później - wraz z pierwszymi sukcesami w nawiązywaniu kontaktu.

Narracja filmu (niczym treść przepowiedni) od samego początku stanowi dla odbiorcy zagadkę. Już otwarcie filmu ma na celu pokazanie mu, jak wiele zależy od interpretacji. Sekwencja montażowa przedstawiająca fragment życia Louise od urodzin jej córki do jej śmierci w nastoletnim wieku sugeruje, że to wszystko wydarzyło się to w przeszłości. Gdy zatem w następnej scenie ponownie pojawia się

serialu HBO Westworld (2020) - dokonywano ich jednak nie na podstawie proroctw, lecz możliwego do precyzyjnego wyliczenia potencjału danej osoby. 
Louise, wskutek działania efektu Kuleszowa widzimy w niej smutek po stracie dziecka. W rzeczywistości jednak Hannah nawet się jeszcze nie urodziła, a cała sekwencja była futurospekcją[32].

Okoliczności narodzin, życia i śmierci dziecka będą głównym przedmiotem tragicznych wizji Louise. Kobieta widzi bowiem tylko własne życie - nie ma dostępu do wydarzeń ważnych w skali globalnej innych niż te, w których sama odegrała kluczową rolę. Wieszczy zatem przez pryzmat własnych emocji, jednak - co istotne - nie daje się im ponieść, zwłaszcza tym negatywnym. Jest to możliwe, ponieważ Louise rozumie naturę swoich wizji: nie są one jedynie „zarodkiem przyszłego wydarzenia”, ale czymś, co jednocześnie wydarzy się, wydarza się i wydarzyło się. Po prostu faktem. W obliczu tego wszelkie działanie ma więc na celu „nadanie mocy chronologii”, a język służy nie przekazywaniu informacji, ale „urzeczywistnianiu”[33]. Możliwość wglądu w przyszłość jest zatem wynikiem poznania języka przybyszy heptapodów, a Louise najpełniej ze wszystkich ludzi potrafi korzystać z jego możliwości nie ze względu na bycie wybraną lub naznaczoną, ale przede wszystkim dzięki swoim językoznawczym kompetencjom. Przywołana przez nią w jednym z dialogów hipoteza Sapira-Whorfa ma tłumaczyć ten proces: język kształtuje sposób patrzenia na rzeczywistość. W opowiadaniu Chianga Louise Banks wyjaśnia to obszerniej: „U ludzi rozwinęła się świadomość sekwencyjna, natomiast u siedmionogów jednoczesna. My doświadczaliśmy wydarzeń po kolei i postrzegaliśmy związki między nimi w kategoriach przyczyny i skutku, one zaś doświadczały wszystkich wydarzeń jednocześnie i dostrzegały kryjący się za nimi cel"[34].

Koncepcja jednoczesnego przeżywania przeszłości, teraźniejszości i przyszłości upowszechniona została w popkulturze między innymi przez postać Doktora Manhattana z komiksu Strażnicy, a za sprawą filmowych i serialowych adaptacji komiksu zafunkcjonowała również na ekranach. Wydaje się jednak, że już w greckim antyku w łudząco podobny sposób przedstawiano wizje wieszczów. W Agamemnonie uwidacznia się to w exodosie, gdy Kasandra doświadcza przyszłości i relacjonuje ją chórowi w czasie teraźniejszym. Michael Attyah Flower zauważa, że również delficka Pytia widziała czas oraz przestrzeń całościowo, co miało odwzorowywać boską perspektywę Apolla[35]. Prawie tak samo opisuje oddziaływanie języka heptapodów literacka Louise: „Doświadczam wtedy przeszłości i przyszłości jednocześnie. Moja świadomość staje się długim na pół stulecia węgielkiem płonącym poza czasem"[36].

[32] Por. A. Majer, Narracja czasem. Analiza struktury narracyjnej filmu „Arrival” (2016) Denisa Villeneuve'a, „Images. The International Journal of European Film, Performing Arts and Audiovisual Communication" 2020, vol. XXVIII, nr 37.

[33] Doprecyzowania pochodzą z opowiadania Teda Chianga. T. Chiang, Historia twojego życia, tłum.
M. Jakuszewski, [w:] Historia twojego życia, Poznań 2016 [e-book].

[34] Ibidem.

[35] M.A. Flower, The Seer in Ancient Greece, Berkeley, Los Angeles, London 2008, s. 211.

[36] T. Chiang, op.cit. 
Początkowo strzępy wizji pokazywane są w Nowym początku $\mathrm{w}$ formie rozbijających wizualną ciągłość przebitek i w pierwszym spojrzeniu nietrudno wziąć je za flashbacki. Prawdziwa natura wizji zostaje ostatecznie rozpoznana przez Louise w mistycznej aurze spotkania $z$ heptapodem sam na sam. Kobieta trafia wówczas do jasnej przestrzeni, gdzie ukazywana jest w slow motion, w wysokim kluczu oświetleniowym, często w zbliżeniach i w centralnej pozycji w kadrze przypomina wówczas do złudzenia Kasandrę z portretu Fredericka Sandysa z 1885 roku. Ponadto niemal identyczny sposób filmowania pojawiał się już Raporcie mniejszości, Terminatorze 2 i 12 małpach zawsze wtedy, gdy postacie przeżywały swoje wizje. Mistyczna natura tych momentów może nie znajdować uzasadnienia w fabułach filmów, jednak sposób ich ekranowego obrazowania w każdym przypadku komunikuje wyjątkowość chwil, w których wieszcz zostaje wyrwany ze swojej teraźniejszości.

Bezpośrednie nawiązania do kultów apollińskich u Villeneuve'a nie występują - przeciwnie, na poziomie ideowej wymowy ważniejsze wydaje się uwolnienie źródła profetyzmu spod wpływu zwodniczego i mściwego bóstwa. Według Laurie Layton Schapiry historia mitologicznej Kasandry miała dziać się w epoce brązu, w drugim tysiącleciu przed naszą erą. W tym czasie w świecie greckim dokonywało się przejście od kultury matriarchalnej do patriarchalnej. Kiedy więc Troja, ojczyzna Kasandry, została podbita przez Greków, jej wartości (bliższe porządkowi kreteńskiemu i minojskiemu, a więc matriarchalnemu) zostały zastąpione przez dążący ku patriarchatowi porządek achajski[37]. Zmiana ta widoczna jest również w treści greckich mitów. Nie tylko w historii odrzucenia Apolla przez Kasandrę i jego okrutnej zemsty. Również w opowieści o zabiciu delfickiego Pytona przez tego samego boga i ustanowienia na jego zwłokach własnej wyroczni, Pytii. Bowiem na długo przed tym, jak Delfy stały się ośrodkiem kultu apollińskiego, były miejscem poświęconym bogini ziemi, Gai. Pyton natomiast aż do swojej śmierci strzec miał wejścia do jej świątyni[38].

W tym kontekście szczególnie ważne wydaje się, że Louise ani przez moment nie jest postrzegana inaczej niż przez pryzmat swojego profesjonalizmu. Nie jest już szaloną wieszczką, która mówi tak niezrozumiale, że potrzebuje tłumacza (o to apelował u Ajschylosa przewodnik chóru, w. 1061) - nie ma przecież zdolniejszych tłumaczy od niej samej. Jej słowa nie potrzebują również interpretacji mędrców-kapłanów, choć i w tej rzeczywistości politycznej znalazłoby się wielu chętnych do przyjęcia tej roli z zamiarem forsowania własnej narracji. Gdy heptapody na pytanie o cel przybycia na ziemię odpowiadają: "oferta broni” (offer weapon), rządzący i wojsko przyjmują ich słowa za akt agresji. Tymczasem Louise docieka, czy przybysze na pewno rozu- 
mieją różnicę między słowami „broñ” i „narzędzie”. Dąży do tego, by wyzwolić ludzkie myślenie z systemu pojęć, którym sami się spętaliśmy. Dlatego za błąd uważa komunikowanie się z przybyszami za pomocą mahjonga - gry, która zamyka komunikację w kręgu pojęć związanych z rywalizacją i narzuca dualistyczne postrzeganie rzeczywistości w kategoriach porażki i sukcesu. Jeśli masz do dyspozycji jedynie młotek, wszystko staje się gwoździem, w który należy uderzyć.

Niewiara w słowa Louise jako kulturowej spadkobierczyni Kasandry ma zatem dość przewrotny przebieg. Gdy wszyscy oczekują od niej potwierdzenia nadchodzącej katastrofy, ona przekonuje, że tym razem katastrofy nie będzie. Patriarchalny świat, który głównej wartości upatruje w sile, chce znać zamiary wroga po to, by zaatakować go z wyprzedzeniem. Ostateczne zwycięstwo wieszczki ujawni fundamentalne ograniczenia tego świata. Czy jej płeć ma w tym wypadku kluczowe znaczenie? Przypuszczalnie taki sam efekt mógłby być osiągnięty przez protagonistę każdej płci. Louise nie nawołuje przecież do powrotu do matriarchatu (choć dla niej samej macierzyństwo jest bardzo istotne), ale zdecydowanie wzywa do nierozpatrywania rzeczywistości poprzez jeden tylko system pojęć. Natomiast jako wieszczka-kobieta w najbardziej reprezentatywny sposób pokazuje drogę, jaką Kasandra przeszła przez wieki - od upokorzonej przez niedoszłego boskiego kochanka figury bezsilności do profesjonalistki zdolnej w pojedynkę zatrzymać katastrofę, którą świat sam sobie chciał zgotować.

Mitologiczna Kasandra wydaje się najbardziej potrzebna filmowej popkulturze jako pośredniczka między względnie bezpieczną teraźniejszością a nieznaną przyszłością. Poczucie schyłku tej pierwszej rodzi potrzebę urzeczywistnienia tego, co może nastąpić. Kasandra ujawnia się jako dobra przewodniczka po nawet najbardziej katastroficznych wizjach. Jednak współczesność wymaga od niej sprawczości, którą ludzkość będzie mogła przeprojektować na siebie. We współczesnej mitologii jest zatem miejsce dla Kasandry niezłomnej, stawiającej opór niesprawiedliwości, wskazującej błędy i proponującej rozwiązania. I przede wszystkim: zdolnej do efektywnego komunikowania swoich intencji. To Kasandra, jakiej chcemy uwierzyć - czyli de facto: uwolniona od klątwy Apolla. Tak rozumiana figura wieszczki ma szansę uwypuklić afirmatywną wizję ludzkości, która uczy się na błędach, współpracuje, a za 3000 lat może nawet będzie w stanie pomóc zaprzyjaźnionym kosmitom.

Wydaje się jednak, że póki co w popkulturowej mitologii XXI wieku wciąż jeszcze niepodzielnie panuje mit herosa. Człowieka o cechach boskich, który prędzej siłą mięśni pokaże obcym drogę do domu niż się z nimi skomunikuje. Pozostaje mieć nadzieję, że zdążymy spotkać na swojej drodze Kasandrę zanim nieznana przyszłość nadejdzie naprawdę. 
Abramowska J., Powtórzenia i wybory. Studia z tematologii i poetyki historycznej, Poznań 1995

Arnheim R., Epic and dramatic film, „Film Culture” 1957, nr 3

Chiang T., Historia twojego życia, thum. M. Jakuszewski, [w:] Historia twojego życia, Poznań 2016 [e-book]

Colli G., Narodziny filozofii, wstęp i tłum. S. Kasprzysiak, Warszawa, Kraków 1991

Flower M.A., The Seer in Ancient Greece, Berkeley, Los Angeles, London 2008

Goethe J.W., O poezji epickiej i dramatycznej, [w:] Goethe i Schiller o dramacie i teatrze. Wybór pism, tłum. i oprac. O. Dobijanka-Witczakowa, Kraków 1996

Graves R., Mity greckie, tłum. H. Krzeczkowski, Kraków 2009

Kott J., Tragedia grecka i absurd, [w:] J. Kott, Zjadane bogów. Szkice o tragedii greckiej, Kraków 1986

Leder A., Paradoks a filozofia. Niesamoistność człowieka w Grecji archaicznej, „Sztuka i Filozofia" 2003, nr 22-23

Majer A., Narracja czasem. Analiza struktury narracyjnej filmu „Arrival” (2016) Denisa Villeneuvea, „Images. The International Journal of European Film, Performing Arts and Audiovisual Communication" 2020, vol. XXVIII, nr 37

Piętka R., Profetyzm i historia. Temat Sybilli w literaturze dawnej i dwudziestowiecznej, [w:] Narracja, historia, fikcja. Dawne kultury w historiografii i literaturze, red. Ł. Grüzmacher, Warszawa 2009

Platon, Timaios, Fajdros [w:] Platon, Dialogi, oprac. W. Witwicki, Warszawa 2004

Schapira L.L., The Cassandra Complex: Living with Disbelief. A Modern Perspective on Hysteria, Toronto 1988

Sontag S., Katastrofa w wyobrażeniu, [w:] S. Sontag, Przeciw interpretacji i inne eseje, tłum. A. Skucińska, Kraków 2012

Stempowski J., Esej dla Kassandry, [w:] J. Stempowski, Eseje dla Kassandry, red. P. Kłoczowski, Gdańsk 2005

Sutton T.C., Sutton M., Science fiction as mythology, „Western Folklor” 1969, vol. 28, nr 4.

Wesołowska E., Dwie lub trzy Kasandry i co o nich wiem. Kilka uwag, „Prace Filologiczne. Literaturoznawstwo" 2014, nr 4(7) 